\title{
Performance Assessment of Real Estate Investment Trusts (REIT) Listed in BIST Via Different Multi Criteria Decision Making Methods
}

\author{
Namik Kemal Erdogan ${ }^{1}$, Serpil Altinirmak ${ }^{2} \&$ Caglar Karamasa ${ }^{1}$ \\ ${ }^{1}$ Faculty of Business, Anadolu University, Eskisehir, Turkey \\ ${ }^{2}$ Eskisehir Vocational High School, Anadolu University, Eskisehir, Turkey \\ Correspondence: Caglar Karamasa, Faculty of Business, Anadolu University, Yunusemre Campus, 26470, \\ Eskisehir, Turkey. Tel: 90-539-522-2803. E-mail: ckaramasa@ anadolu.edu.tr
}

Received: April 20, 2016

Accepted: May 18, 2016

Online Published: June 25, 2016

doi:10.5539/ijef.v8n7p304

URL: http://dx.doi.org/10.5539/ijef.v8n7p304

\begin{abstract}
Firms' performance assessment which gained crucial importance in last decades is essential issue for decision makers in financial sector. They can acquire competitive power by this way. In this study financial performance of twelve real estate investment trusts (REITs) listed in BIST is analyzed by using four financial indicators within the period of 2011-2015. Therefore firstly weights of criteria related to financial ratios are obtained by using Chang's Extent Analysis Method on Fuzzy Analytic Hierarchy Process (FAHP). Following to this firms' final rankings are determined by means of TOPSIS (Technique for Order Preference by Similarity to Ideal Solution) and VIKOR (Vise Kriterijumska Optimizacija I Kompromisno Resenje) methods respectively. Also ranking performance of these two methods is interpreted.
\end{abstract}

Keywords: performance analysis, multi criteria decision making, analytic hierarchy process, TOPSIS, VIKOR, real estate investment trust, BIST

\section{Introduction}

Real Estate Investment Trusts (REITs) are established with aim for investing high return potential real estates and real estate based projects also making profit from real estate leasing and commerce. Portfolio earnings of REITs are distributed to shareholders as dividends within the frame of capital markets board regulations in the year-end (https://www.sec.gov).

REITs are only operated within the concept of real estate based portfolio management and hence machine and equipment are not contained in their assets. Furthermore they do not undertake the responsibility of civil works and conduct a project but finance civil projects under the responsibility of other companies.

Real estates and real estate based investments develop psychological trust for investors. Earnings of REITs are exempt from corporation tax. While nine REITs are listed in IMKB in 2009, thirty two REITs are listed in BIST nowadays (http://www.spk.gov.tr).

Studies about real estate investment trusts (REITs) are introduced in USA since 1970s. First studies are aimed to evaluate the performance of REITs. There are no more studies about REITs, developed in 1990s and 2005, in other countries. Studies in Turkey which is introduced from 2000s depend on process and legal infrastructure of REITs. According to the literature this study is one of the rare ones based on analyzing the performance of REITs traded in Turkey via multi criteria decision making methods.

\section{Financial Performance Indicators}

While financial indicators are used for specifying the firms' value by investors and shareholders; they are utilized by creditors for determining solvency capacity and financing costs. Valuation models determining firms' market value can be classified into accounting and financial models. According to the accounting ones firm value is considered as a function of a number of variables such as profit margin, earnings per share, profitability growth ratio, cash flows, book value and dividends.

With respect to financial models firm value is handled as a function of yield capacity from available assets and potential investments, return level and cost of capital. It is pointed out the superiority of economic value added (EVA) over other indicators in revealing the firms' real value. Financial indicator namely EVA was used for 
detecting financial performance and purpose of firms, projects planned to invest and intellectual capital (Baybordi, Barvari, Bahramihajlabad, \& Sheykhlov, 2013, p.1307).

A number of studies measuring firms' financial performance are based on comparing the effect of value based performance indicators and traditional ones. Lehn and Makhija (1997) found out the outstanding performance of EVA over traditional based indicators. As opposed to that Biddle, Bowen and Wallace (1997) revealed the superiority of accounting based indicators. Chen and Dodd (1998) analyzed the efficiency of operating profit, residual income and EVA in firm valuation and did not find the EVA as the most effective one. Acheampong and Wetzstein (2001) stressed the indifference between value based indicators and traditional ones and asserted the joint consideration. Worthington and West (2004) concluded that the effectiveness of EVA usage in determining stock yield than traditional performance indicators such as net cash flows and residual income.

Superiority of performance indicators change according to the application field. Therefore REITs, inadequate interest shown by researchers, are considered in this study. Both traditional performance indicators (return on assets, residual income and return on sales) and value based ones (EVA) are used for measuring the performance of REITs. In addition to this firms are compared with regard to multi criteria decision making (MCDM) methods.

\subsection{Return on Assets}

Return on assets degrades profit/cost and investments into a ratio by dealing the concept of profitability. Furthermore it is one of the commonly used performance ratios for comparing the return of assets in terms of firms' investments which are made or planned.

The ratio of return of assets (ROA) shows how firms efficiently used their total assets and calculated by various ways:

$$
\begin{gathered}
\text { Return of Assets }=\text { Profit/Total Assets } \\
\text { Return of Assets }=\text { Return on Sales } x \text { Investment Turnover }
\end{gathered}
$$

According to the different viewpoints profit, shown in Eq. (1), can be treated as operating profit or net profit. Similarly total assets, depicted in Eq. (1), can be considered as firms' assets held or computed as total assets short term debts according to different applications (Yükçü \& Atağan, 2009, p. 9).

\subsection{Residual Income}

Investors desire firms being appreciate and want to see the result of their investments. Ratios namely net return on investments (ROI) and residual income are used for this purpose. In addition to the similarity between ratios; while ROI is depicted as percentage residual income is shown as amount. This is the reason for preferring residual income by managers.

Although item namely cost of financial sources are available in the income statement, it is not true for owner's equity. Therefore added value is calculated as subtracting cost of equity from net income in case of determining cost for owner's equity. According to the Öztürk (2010), who made a study aimed at examining the manufacturing firms listed in BIST, firms should focus on residual income that will create value for shareholders and increasing their market value.

According to the method of residual income expected return on capital is generally assumed as constant and equity expenditures in the ith year are calculated as multiplying return on equity by the book value of equity at the beginning of year (Yavuzarslan, 2007, pp. 11-17).

$$
\begin{gathered}
\text { Equity Expenditures }=\text { Book value of equity } x \text { expected return on capital } \\
\text { Residual income }=\text { Net income }- \text { Capital expenditures }
\end{gathered}
$$

Different approaches and formulations are used for defining the residual income. According to Yükçü (2007) residual income is formulated as:

$$
\text { Residual income }=\text { Operating profit }-(\text { Expected income } x \text { Total assets })
$$

If residual income is positive added value is created otherwise it is lost.

\subsection{Economic Value Added (EVA)}

The ratio of economic value added (EVA) is introduced in the early period of 1980s. EVA, which ignores the cost of capital, is mostly used method to avoid the misleading effect of accounting based traditional performance indicators. A number of big businesses like Coca-Cola, IBM, Whirlpool use this method in planning and performance auditing.

EVA aims to calculate the value that is created via firms' sources in a period. Variables which is unavailable in 
accounting records are used for this purpose and so developments in the sector can be measured. EVA, in which economic value is used as basic one, provides analyzing the effects of growth in terms of whole business and its' parts. EVA, which considers the cost of equity and resource, is an indicator of earnings exceeding the cost of capital and differs from the performance indicators like earnings per share, ROA and return on equity. EVA can be formulated as below:

$$
\text { EVA = Net Operating Profit Less Adjusted Taxes - (Invested Capital } x \text { Weighted Average Cost of Capital) }
$$

$$
E V A=(\text { Return on Invested Capital }- \text { Weighted Average Cost of Capital }) x \text { Invested Capital }
$$

According to Eq. (6) firm creates added value if the value of EVA being positive in other words the value of net operating profit less adjusted taxes exceeds the capital expenditures. Value of EVA can be increased by decreasing the capital expenditures or raising the net operating profit less adjusted taxes (Yavuzarslan, 2007, p. 39)

There are some difficulties in calculating the value of EVA such as the weighted average cost of capital. Weighted average cost of capital can be computed as below:

$$
\begin{gathered}
\text { Weighted Average Cost of Capital }=(\text { Debt Ratio } x \text { Cost of Debt After Taxes })+ \\
\text { (Ratio of Owner's Equity x Cost of Equity) }
\end{gathered}
$$

\subsection{Return on Sales}

Return on sales which is one of the commonly used performance indicator is easily computed and formulated as below:

\section{Literature Review}

$$
\text { Return on Sales = Operating Profit/Sales }
$$

Smith and Shulman (1976) compared the performances of REITs operated in USA with S\&P index, savings accounts and 15 investment funds in the period of 1963-1974. With this aim capital assets pricing model (CAPM) is used. As a result sample consisted of REITs outperform than other indicators within the period of 1963-1974.

Han and Liang (1985) evaluated the return performance of REITs within the period of 1970-1993. According to the Jensen model results, REITs similarly perform with market portfolio and treasury bills. Titman and Warga (1986) examined the performance of REIT shares within the period of 1973-1982 via CAPM and arbitrage pricing model (APM). According to their results REITs based portfolio similarly perform with market portfolio.

Kuhle and Walther (1987) compared the net income values of 102 REITs in the period of 1973-1984. Goebel and Kim (1989) examined the return performance of portfolio consisted of finite life real estate investment trusts (FREITs) in the period of 1983-1987. With this aim Jensen's performance measure is used.

Mcintosh et al. (1991) investigated the relationships between size of enterprise and return of REITs for the period of 1974-1988 and found significant negative relation. Peterson and Hsieh (1997) studied the effect of market value/book value and size of enterprise on the return of REITs and found significant positive relation between return of REITs and size of enterprise and market value/book value respectively.

Chen, Hsieh, Vines, and Chiou (1998) analyzed the return performances of capital based REITs listed in NYSE, AMEX and NASDAQ stock exchanges within the period of 1978-1994. Buttimer, Hyland and Sanders (2001) analyzed the long term performance of REITs by using FAMA and French's three factor model in the period of 1990-1999.

Bley and Olson (2005) examined the performances of equity based REITs, mortgaged REITs and S\&P 500 indexes in the range of 1973-2001. Equity based REIT index has high correlation and return on risks than mortgaged REIT index.

Glascock, Lu, and So (2006) made a study in terms of real estate markets in Asia like Taiwan, Japan, Hong Kong, South Korea, Thailand and Singapore within the period of 1980-1990. With this purpose income behavior of public companies, invest in real estate, are analyzed via regression models and supernormal rate of return is found in Taiwan real estate market apart from other markets.

Bond and Glascock (2006) examined the performance and portfolio diversification characteristics of publicly traded REITs within the period of 1990-2005. According to the results REITs contribute to portfolios as risk mitigant and income promoter. Additionally it is determined that REITs outperform than other shares in recession period.

Derwall, Huij, Brounen, and Marquering (2009) aimed to analyze the explanatory power of momentum factor in 
defining the return of REITs. With this aim monthly returns of REITs traded in the period of 1980-2006 are handled. As a result momentum factor is considered as an essential explanatory in making valuation the portfolio performance.

Yong et al. (2009) assessed the sensitivity of return of REITs, traded in Australia, on the firm related variables. Data is acquired via panel regression analysis in the period of 1990-2008. It is found significant negative relation between size of enterprise and return of REITs, conversely significant positive relation between return of REITs and market value/book value and degree of leverage are obtained respectively.

Chang and Chang (2010) researched the effects of firm size, market value/book value and degree of leverage on return of REITs by using Fama and French three factor model. According to the study results there is significant negative relation between firm size and return of REITs. On the other hand, there is no significant relation between degree of leverage and return of REITs.

Studies aimed to reveal relationship between size of enterprise and return of REITs are made by Chen et al. (1998), Marts and Elayan (1990) and similar results are gained. Accordingly relationship between market value/book value and return of REITs are found out by Bers and Springer (1997), Goebel et al. (2013) and Niskanen et al. (2011). Similar results are valid for this relationship (Şahin, 2014; pp. 11-12).

Studies made in Turkey are not enough as well as can be summarized as below:

Akçay (2000) evaluated the specifications and applications of REITs in Turkey. Performances of REITs are examined from 1997, first public offering time, to June 1999 and compared with return performances of other investment tools. As a result performances of REITs are changed by years.

Yetkin (2004) handled the applicability of balanced score card (BSC) on REITs traded in Turkey and concluded that traditional measuring and management models lose validity. For this reason REITs can use BSC model in order to provide successful and efficient performance management.

Güven (2006) found the factors affecting the stock yield of REITs by means of multivariable regression model. For this purpose return index of REITs are considered as outcome variable, on the other hand BIST 30 index, government debt securities, exchange rate and consumer price indices are treated as independent variables. As a result return ratio of BIST 30 index and exchange increase rate are found as the most significant variables affecting return index of REITs.

Özdemir and Türker (2007) studied the effects of inflation and interest ratios on REITS traded in Turkey. According to the study results REITs perform similarly or better than the return of market portfolio in the years 2002-2006.

\section{Methodology}

\subsection{Analytic Hierarchy Process (AHP)}

Analytic Hierarchy Process (AHP), developed by T. L. Saaty (1980), is a decision making mechanism composed of overall goal, criteria and sub criteria (if there are any), and alternatives. AHP considers rational and intuitive domains to select the best alternative evaluated with respect to several criteria and sub criteria (Bhushan \& Rai, 2004, p. 15). AHP considers subjective and objective opinions of decision makers in decision process and provide them to aggregate tangible quantitative and intangible qualitative factors (Saaty, 1990, p. 20).

AHP decomposes complex decision problem into a tree hierarchy composing of objectives, criteria, sub criteria (if needed) and alternatives. The aim of AHP is to weight criteria and indicators by pairwise comparisons. Importance of elements in a given level is judged with regard to some or all of the elements in adjacent level via pairwise comparisons (Zhou, Maumbe, Deng, \& Selin, 2015, p. 72). By using AHP we can decouple problem into sub problems by evaluating subjectively manner that is transformed into numerical values and ranked on a numerical scale (Bhushan \& Rai, 2004, p. 15).

Phases of AHP can be summarized as follows (Bhushan \& Rai, 2004, p. 15):

a) Problem is defined and decomposed into hierarchy of goal, criteria, sub criteria and alternatives which shows relationship between components at each level. At each level of comparison decision maker consider contribution of lower level components to upper level one.

b) Data is collected from experts or decision makers that can be analyzed as pairwise comparison on fundamental scale representing intensities of judgments. Fundamental scale for multiple pairwise comparisons developed by Saaty and Vargas (2012) and showed in Table 1. 
Table 1. Fundamental scale

\begin{tabular}{|c|c|c|}
\hline Intensity of Importance & Definition & Explanation \\
\hline 1 & Equal importance & Two activities contribute equally to the objective \\
\hline 3 & Moderate importance & Experience and judgment slightly favor one activity over another \\
\hline 5 & Strong importance & Experience and judgment strongly favor one activity over another \\
\hline 7 & Very strong or demonstrated importance & $\begin{array}{l}\text { An activity is favored very strongly over another; its dominance } \\
\text { demonstrated in practice }\end{array}$ \\
\hline 9 & Extreme importance & $\begin{array}{l}\text { The evidence favoring one activity over another is of the highest } \\
\text { possible order of affirmation }\end{array}$ \\
\hline $2,4,6,8$ & Intermediate values & \\
\hline
\end{tabular}

c) Pairwise comparison matrix is constructed and organized into square matrix. These matrices are positive and reciprocal $\left(a_{i j}=1 / a_{j i j}\right)$. If the value of component $(i, j)$ is greater than 1 , criterion in the ith row is better than the jth one. Each element in upper level is used to compare with lower level ones with regard to it (Saaty, 2008).

d) Local and global weights of each criteria and sub criteria are calculated, and the principle right eigenvector $(\omega)$ and largest eigenvalue $\left(\lambda_{\max }\right)$ are obtained. By using discrete paired comparisons ratio scales are derived in form of normalized right eigenvectors. Components of normalized eigenvector are determined as weights and ratings with regard to criteria/ sub criteria and alternatives.

e) Consistency of matrix is evaluated by means of consistency ratio (CR). Quality of AHP depends on consistency of pairwise comparisons. If all comparisons are perfectly consistent $a_{i j}=a_{i k} \cdot a_{k j}$ relation is true for any combination of comparisons (Saaty, 1980). If ratio is lower than the threshold value comparisons must be re-evaluated. Consistency ratio, used for determining whether evaluations are sufficiently consistent, is derived by comparing the consistency index (CI) with the appropriate one of the following set of numbers each of which is average random consistency index (RI), developed by Saaty and Vargas (2012) and showed in Table 2, obtained by sample of randomly generated reciprocal matrices. Consistency index of a matrix of comparisons is $\mathrm{CI}=\left(\lambda_{\max }-\mathrm{n}\right) /(\mathrm{n}-1)$ where $\lambda_{\max }$ is the maximum eigenvalue of paired comparison judgement matrix. Saaty suggest that the CR value must be lower than 0,1 .

Table 2. Average random consistency index (RI)

\begin{tabular}{ccccccccccc}
\hline $\mathrm{N}$ & 1 & 2 & 3 & 4 & 5 & 6 & 7 & 8 & 9 & 10 \\
\hline $\mathrm{RI}$ & 0 & 0 & 0.52 & 0.89 & 1.11 & 1.25 & 1.35 & 1.4 & 1.45 & 1.49 \\
\hline
\end{tabular}

Source: T. Saaty \& L.G. Vargas, "Models, Methods, Concepts \& Applications of the Analytic Hierarchy Process (AHP)" (p.9), 2012, Boston: Springer.

f) In order to obtain local weights of each criteria, rating of each alternative is multiplied by weights of sub-criteria and then aggregated. Multiplying these local weights by criteria weights global ratings of alternatives are acquired.

AHP has been applied in a number of fields such as quality based investment (Güngör \& Arıkan, 2007), machine and equipment selection (Ching \& Been, 1996), purchasing decision process (Byun, 2001), strategic management (Yüksek \& Akın, 2006), site selection decision (Chuang, 2001), performance measuring (Frei \& Harker, 1999), resource allocation (Alphonce, 1997), sustainable city logistics planning (Awasthi \& Chauhan, 2012), project selection (Amiri, 2010), maintenance strategy selection (Bevilacqua \& Braglia, 2000), supplier selection planning model (Hwang, Moon, Chuang, \& Goan, 2005), human performance improvement (Albayrak \& Erensal, 2004), treatment selection (Richman et al., 2006).

\subsection{Chang's Extent Analysis}

Chang (1996) proposed an approach for dealing FAHP by using triangular fuzzy numbers for pairwise 
comparison and considering extent analysis for synthetic extent values of comparisons. Let $X=\left\{x_{1}, x_{2}, \ldots, x_{n}\right\}$ be an object set and $U=\left\{u_{1}, u_{2}, \ldots, u_{n}\right\}$ be a goal set. According to Chang's (1996) extent analysis each objective is taken and extent analysis for each goal is performed respectively. So m extent analysis values for each object can be obtained with the following signs:

$$
M_{g_{i}}^{1}, M_{g_{i}}^{2}, \ldots, M_{g_{i}}^{m}, \quad i=1,2, \ldots, n
$$

Where all the $M_{g_{i}}^{j}(j=1,2, \ldots, m)$ are triangular fuzzy numbers. Steps of Chang's extent analysis (1996) can be given as follows:

1-The value of fuzzy synthetic extent with respect to the ith object is defined as:

$$
S_{i}=\sum_{j=1}^{m} M_{g_{i}}^{j} \otimes\left[\sum_{i=1}^{n} \sum_{j=1}^{m} M_{g_{i}}^{j}\right]^{-1}
$$

To obtain $\sum_{j=1}^{m} M_{g_{i}}^{j}$ the fuzzy addition operation of $m$ extent analysis values for a particular matrix is performed such as

$$
\sum_{j=1}^{m} M_{g_{i}}^{j}=\left(\sum_{j=1}^{m} l_{j}, \sum_{j=1}^{m} m_{j}, \sum_{j=1}^{m} u_{j}\right)
$$

and to obtain $\left[\sum_{j=1}^{n} \sum_{j=1}^{m} M_{g_{i}}^{j}\right]^{-1}$ the fuzzy addition operation of $M_{g_{i}}^{j}(j=1,2, \ldots, m)$ values is performed such as:

$$
\sum_{i=1}^{n} \sum_{j=1}^{m} M_{g_{i}}^{j}=\left(\sum_{i=1}^{n} l_{i}, \sum_{i=1}^{n} m_{i}, \sum_{i=1}^{n} u_{i}\right)
$$

and then the inverse of the vector above is computed such as

$$
\left[\sum_{i=1}^{n} \sum_{j=1}^{m} M_{g_{i}}^{j}\right]^{-1}=\left(\frac{1}{\sum_{i=1}^{n} u_{i}}, \frac{1}{\sum_{i=1}^{n} m_{i}}, \frac{1}{\sum_{i=1}^{n} l_{i}}\right)
$$

2-The degree of possibility of $M_{2}=\left(l_{2}, m_{2}, u_{2}\right) ; M_{1}=\left(l_{1}, m_{1}, u_{1}\right)$ is defined as:

$$
V\left(M_{2} \geq M_{1}\right)=\sup _{y \geq x}\left[\min \left(\mu_{M_{1}}(x), \mu_{M_{2}}(y)\right)\right\rfloor
$$

and can be expressed as follows:

$$
\begin{aligned}
V\left(M_{2} \geq\right. & \left.M_{1}\right)=h g t\left(M_{1} \cap M_{2}\right)=\mu_{M_{2}}(d) \\
& =\left\{\begin{array}{l}
1, \text { if } m_{2} \geq m_{1} \\
0, \text { if } l_{1} \geq u_{2} \\
\frac{l_{1}-u_{2}}{\left(m_{2}-u_{2}\right)-\left(m_{1}-l_{1}\right)} \text { otherwise }
\end{array}\right.
\end{aligned}
$$

Eq. (16) where $\mathrm{d}$ is the ordinate of the highest intersection point $\mathrm{D}$ between $\mu_{M_{1}}$ and $\mu_{M_{2}}$ is illustrated in 
Figure 1 (Chang, 1996). To compare $M_{1}$ and $M_{2}$, we need both the values of $V\left(M_{1} \geq M_{2}\right)$ and $V\left(M_{2} \geq M_{1}\right)$.

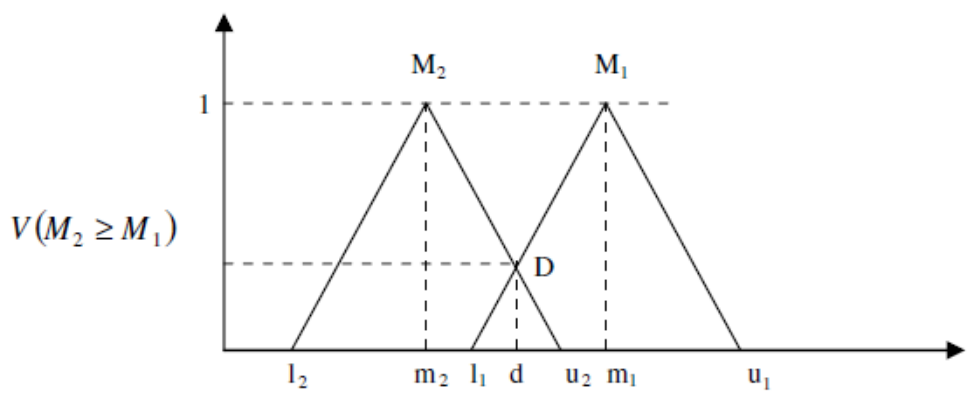

Figure 1. The definition of the degree of possibility of $\left.\mathrm{V}_{(\mathrm{M}} \geq \mathrm{M}_{1}\right)$

Source: Chang, D. Y. (1996). Applications of the extent analysis method on fuzzy AHP. European Journal of Operational Research, $95,651$.

3-The degree possibility for a convex fuzzy number to be greater than $\mathrm{k}$ convex fuzzy $M_{i}(i=1,2, \ldots, k)$ numbers can be defined by

$$
\begin{aligned}
& V\left(M \geq M_{1}, M_{2}, \ldots, M_{k}\right)=V\left[\left(M \geq M_{1}\right) \text { and }\left(M \geq M_{2}\right) \text { and } \ldots \text { and }\left(M \geq M_{k}\right)\right\rfloor \\
& =\min V\left(M \geq M_{i}\right), i=1,2, \ldots, k
\end{aligned}
$$

Assume that $d\left(A_{i}\right)=\min V\left(S_{i} \geq S_{k}\right)$ for $\mathrm{k}=1,2, \ldots, \mathrm{n} ; k \neq i$.Then the weight vector is given by

$$
W^{\prime}=\left(d^{\prime}\left(A_{1}\right), d^{\prime}\left(A_{2}\right), \ldots, d^{\prime}\left(A_{n}\right)\right)^{T}
$$

where $A_{i}(i=1,2, \ldots, n)$ are $\mathrm{n}$ elements.

4-Via normalization, the normalized weight vectors are:

$$
W=\left(d\left(A_{1}\right), d\left(A_{2}\right), \ldots, d\left(A_{n}\right)\right)^{T}
$$

where $\mathrm{W}$ is a non-fuzzy number.

While computational easiness and compliance with stages of traditional AHP (additional process are not required) can be considered as advantages of this method, allowing only triangular fuzzy numbers, assigning zero weights to some relative importance values and neglecting important information, causing faulty decisions comprise disadvantage side (Wang, Luo, \& Hua, 2008, p. 745).

In order to overcome assigning zero weights to some criteria firstly Saaty's 9 point scale is carried out by decision maker's to construct pair-wise comparison matrix. Then adopting Eq. (21) proposed by Chen, Lin and Huang (2006) decision makers' pairwise comparison values are transformed into triangular fuzzy numbers and comprehensive pairwise comparison matrix is acquired. Let the fuzzy rating and importance weight of the $k$ th decision maker be $\tilde{\mathrm{x}}_{\mathrm{ijk}}=\left(\mathrm{a}_{\mathrm{ijk}}, \mathrm{b}_{\mathrm{ijk}}, \mathrm{c}_{\mathrm{ijk}}\right) ; \mathrm{i}=1,2, \ldots, \mathrm{m}$ and $\mathrm{j}=1,2, \ldots, \mathrm{n}$ respectively. So the aggregated fuzzy ratings $\left(\tilde{X}_{i j}\right)$ of alternatives with respect to each criterion can be calculated as below:

$$
\left(\tilde{\mathrm{x}}_{\mathrm{ij}}\right)=\left(\mathrm{a}_{\mathrm{ij}}, \mathrm{b}_{\mathrm{ij}}, \mathrm{c}_{\mathrm{ij}}\right)
$$

where

$$
\mathrm{1}_{\mathrm{ij}}=\min _{\mathrm{k}}\left\{\mathrm{a}_{\mathrm{ijk}}\right\}, \quad \mathrm{m}_{\mathrm{ij}}=\frac{1}{\mathrm{~K}} \sum_{\mathrm{k}=1}^{\mathrm{K}} \mathrm{b}_{\mathrm{ij} \mathrm{k}}, \quad u_{i j}=\max _{k}\left\{c_{i j}\right\}
$$

4.3 Technique for Order Preference by Similarity to Ideal Solution (TOPSIS)

Hwang and Yoon (1981) assert Technique for Order Preference by Similarity to Ideal Solution (TOPSIS) for 
analyzing multi criteria decision making (MCDM) problems. Basis of this technique is to choose alternative having the shortest euclidean distance from positive ideal solution (PIS) which maximizes benefit and minimizes cost, and the farthest distance from negative ideal solution (NIS) which maximizes cost and minimizes benefit (Behzadian et al., 2012). TOPSIS has been applied in a number of fields such as supplier selection (Shahanaghi \& Yazdian, 2009), facility layout selection (Chu, 2002), performance measurement and evaluation (Yurdakul \& İç,2003), machine tool selection (Yurdakul \& İç, 2009), outsourcing (Bottani \& Rizzi, 2006).

Assumption of this technique is to maximize or minimize each criterion and pairwise comparisons are abstained. Structure of TOPSIS are revealed as follows (Tsaur, 2011):

1- Forming decision matrix $\left(X=\left(x_{i j}\right)_{n x m}\right)$ for ranking the alternatives.

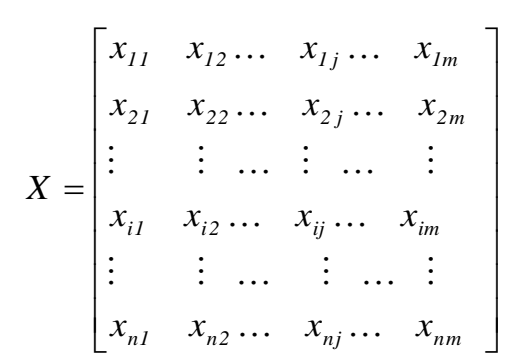

2- Normalizing decision matrix by

$$
r_{i j}=\frac{w_{i j}}{\sqrt{\sum_{i=1}^{m} w_{i j}^{2}}} i=1,2, \ldots, n \quad j=1,2, \ldots, m
$$

3- Weighting normalized decision matrix by multiplying normalized decision matrix and its' weights.

$$
v_{i j}=r_{i j} \cdot w_{j} \quad i=1,2, \ldots, n \quad j=1,2, \ldots, m
$$

4- Determining positive and negative ideal solution as follows:

$$
\begin{gathered}
P I S=A^{*}=\left\{v_{1}^{*}, v_{2}^{*}, \ldots, v_{m}^{*}\right\}=\left\{\left(\max _{i} v_{i j} \mid j \in \Omega_{b}\right),\left(\min _{i} v_{i j} \mid j \in \Omega_{c}\right)\right\} \\
N I S=A^{-}=\left\{v_{l}^{-}, v_{2}^{-}, \ldots, v_{m}^{-}\right\}=\left\{\left(\min _{i} v_{i j} \mid j \in \Omega_{b}\right),\left(\max _{i} v_{i j} \mid j \in \Omega_{c}\right)\right\}
\end{gathered}
$$

5- Calculating Euclidean distance of alternatives from positive and negative ideal solution as follows:

$$
\begin{aligned}
& d_{i}^{*}=\sqrt{\sum_{j=1}^{m}\left(v_{i j}-v_{j}^{*}\right)^{2}} \quad i=1,2, \ldots, n \\
& d_{i}^{-}=\sqrt{\sum_{j=1}^{m}\left(v_{i j}-v_{j}^{-}\right)^{2}} \quad i=1,2, \ldots, n
\end{aligned}
$$

6- Calculating relative closeness of each alternative to ideal solution as below:

$$
R C_{i}=\frac{d_{i}^{-}}{d_{i}^{-}+d_{i}^{*}} \quad i=1,2, \ldots, n \quad R C_{i} \in[0,1]
$$

7- Ranking alternatives according to their $R C_{i}$ values in descending order from 1 to 0 and choosing the highest one.

\subsection{VIKOR (Vise Kriterijumska Optimizacija I Kompromisno Resenje)}

VIKOR (Vise Kriterijumska Optimizacija I Kompromisno Resenje) developed by Opricovic is a multi criteria decision making method (MCDM) based on creating compromised solution by taking alternatives and criteria into the consideration. Method is oriented for selecting and ranking alternatives in case of conflicting criteria (Büyüközkan \& Ruan, 2008). Compromised solution is the closest to ideal one. In other words VIKOR based on measure of closeness to ideal solution is multi criteria decision ranking index (Opricovic \& Tzeng, 2004). In order to obtain solution, closest to ideal one, multi criteria ranking index is generated for alternatives and then 
compared between the values of closeness to ideal solution (Opricovic \& Tzeng, 2007). VIKOR has been applied in a number of fields such as evaluating banking perormance (Wu et al., 2009), public transportation analysis (Tzeng et al., 2005), selection of outsourcing providers (Liou \& Chuang, 2010), material selection (Shanian \& Savadogo, 2009).

Decision making process of VIKOR starts with problem definition. By this way aim of problem, alternatives, criteria and sub criteria (if needed) that will be evaluated are determined. Alternatives are selected, ranked and compared by utilizing cost or benefit based criterias. In evaluation process all alternatives get related criteria scores.

Steps of VIKOR method can be summarized as below:

a) Best $\left(f_{a}^{*}\right)$ and the worst $\left(f_{a}^{-}\right)$values for each evaluation criteria are identified. If evaluation criteria $(b=1,2, \ldots, n)$ is based on benefit ;

$$
\mathrm{f}_{\mathrm{b}}^{*}=\max _{\mathrm{a}} \mathrm{x}_{\mathrm{ab}} \quad \mathrm{f}_{\mathrm{b}}^{-}=\min _{\mathrm{a}} \mathrm{x}_{\mathrm{ab}}
$$

If evaluation criteria $(b=1,2, \ldots, n)$ is based on cost;

$$
\mathrm{f}_{\mathrm{b}}^{*}=\min _{\mathrm{a}} \mathrm{x}_{\mathrm{ab}} \quad \mathrm{f}_{\mathrm{b}}^{-}=\max _{\mathrm{a}} \mathrm{x}_{\mathrm{ab}}
$$

b) In order to make comparisons normalization process is used and by this way normalization matrix is obtained. In normalization process decision matrix $(\mathrm{X})$,composed of $\mathrm{k}$ criteria and 1 alternatives, transformed into normalization matrix $(\mathrm{S})$ with same dimensions. Before normalization decision matrix (X) consisted of elements $\left(\mathrm{x}_{\mathrm{k} 1}\right)$ is seen as below;

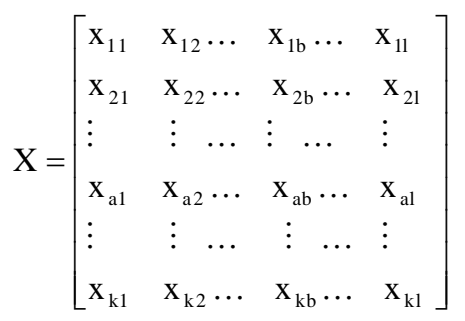

After normalization process normalization matrix $(\mathrm{S})$ consisted of elements $\left(\mathrm{s}_{\mathrm{kl}}\right)$ is seen as below;

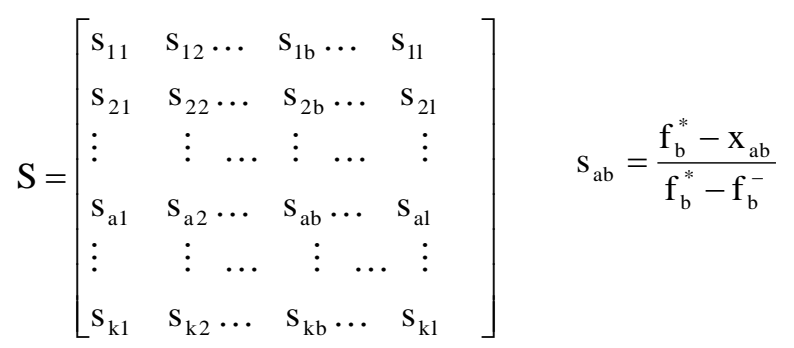

c) Weighted normalized decision matrix $(\mathrm{T})$ is obtained by multiplying criteria weights $\left(W_{b}\right)$ and normalized decision matrix elements $\left(S_{a b}\right)$.

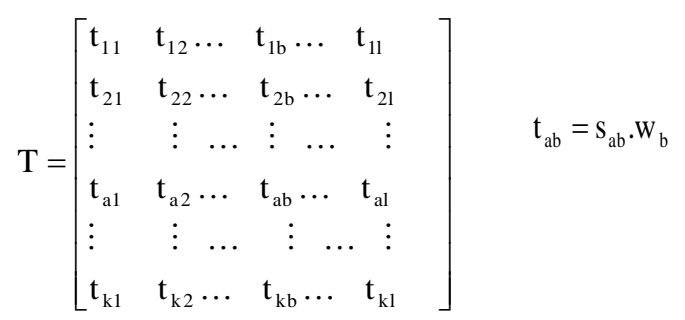

d) Values of $S_{a}$ (mean group score) and $R_{a}$ (worst group score) are calculated for each alternative.

$$
\mathrm{S}_{\mathrm{a}}=\sum_{\mathrm{b}=1}^{1} \mathrm{w}_{\mathrm{b}} \frac{\mathrm{f}_{\mathrm{b}}^{*}-\mathrm{x}_{\mathrm{ab}}}{\mathrm{f}_{\mathrm{b}}^{*}-\mathrm{f}_{\mathrm{b}}^{-}} \quad \mathrm{R}_{\mathrm{a}}=\max _{\mathrm{b}}\left[\mathrm{w}_{\mathrm{b}} \frac{\mathrm{f}_{\mathrm{b}}^{*}-\mathrm{x}_{\mathrm{ab}}}{\mathrm{f}_{\mathrm{b}}^{*}-\mathrm{f}_{\mathrm{b}}^{-}}\right]
$$


e) Value of $Q_{a}$ is calculated for each alternative. Values of $\mathrm{S}^{*}, \mathrm{~S}^{-}, \mathrm{R}^{*}, \mathrm{R}^{-}$are used to acquire the value of $Q_{a}$. Additionally q parameter showing maximum group benefit states the weight of alternative providing maximum group benefit. On the contrary (1-y) parameter refers to weight of minimum regret. Compromise is reached by majority $(q>0.5)$, consensus $(q=0.5)$ or veto $(q<0.5)$ (Opricovic \& Tzeng, 2007). Generally q=0.5 is used (Lixin, Ying, \& Zhiguang, 2008).

$$
\begin{aligned}
& \mathrm{S}^{*}=\min _{\mathrm{a}} \mathrm{S}_{\mathrm{a}} \\
& \mathrm{S}^{-}=\max _{\mathrm{a}} \mathrm{S}_{\mathrm{a}} \quad \mathrm{Q}_{\mathrm{a}}=\mathrm{q} \frac{\mathrm{S}_{\mathrm{a}}-\mathrm{S}^{*}}{\mathrm{~S}^{-}-\mathrm{S}^{*}}+(1-\mathrm{q}) \frac{\mathrm{R}_{\mathrm{a}}-\mathrm{R}^{*}}{\mathrm{R}^{-}-\mathrm{R}^{*}} \\
& \mathrm{R}^{*}=\min _{\mathrm{a}} \mathrm{R}_{\mathrm{a}} \\
& \mathrm{R}^{-}=\max _{\mathrm{a}} \mathrm{R}_{\mathrm{a}}
\end{aligned}
$$

f) Values of $S_{a}, R_{a}$ and $Q_{a}$ are ranked from lower to higher and alternative having minimum $Q_{a}$ value is controlled by two conditions whether ranking is accurate. These conditions are named acceptable advantage and acceptable stability.

Acceptable advantage condition: According to $Q_{a}$ values first $\left(\mathrm{Q}\left(\mathrm{C}_{1}\right)\right)$ and second alternative $\left(\mathrm{Q}\left(\mathrm{C}_{2}\right)\right)$ satisfied significant difference. Calculated threshold value (DQ) depend on the number of alternative. If the number of alternative is lower than 4 the value of DQ equals to 0.25 (Chen \& Wang, 2009).

$$
\mathrm{Q}\left(\mathrm{C}_{1}\right)-\mathrm{Q}\left(\mathrm{C}_{2}\right) \geq \mathrm{DQ} \quad \mathrm{DQ}=\frac{1}{\mathrm{k}-1}
$$

Acceptable stability condition: According to $Q_{a}$ values first alternative $\left(\mathrm{Q}\left(\mathrm{C}_{1}\right)\right)$ should get the best score at least one for values of $\mathrm{S}$ and $\mathrm{R}$. Unless these two conditions are not satisfied, compromised solution set is formed by two ways:

1- If second condition is not satisfied, first and second alternatives are accepted as compromised solution.

2- If first condition is not satisfied, $C_{1}, C_{2}, \ldots, C_{k}$ alternatives are contained in compromised solution set according to $\mathrm{Q}\left(\mathrm{C}_{\mathrm{k}}\right)-\mathrm{Q}\left(\mathrm{C}_{1}\right) \geq \mathrm{DQ}$ (Opricovic \& Tzeng, 2004).

Flowchart of FAHP-VIKOR and FAHP-TOPSIS methodologies are showed in Figure 2. 


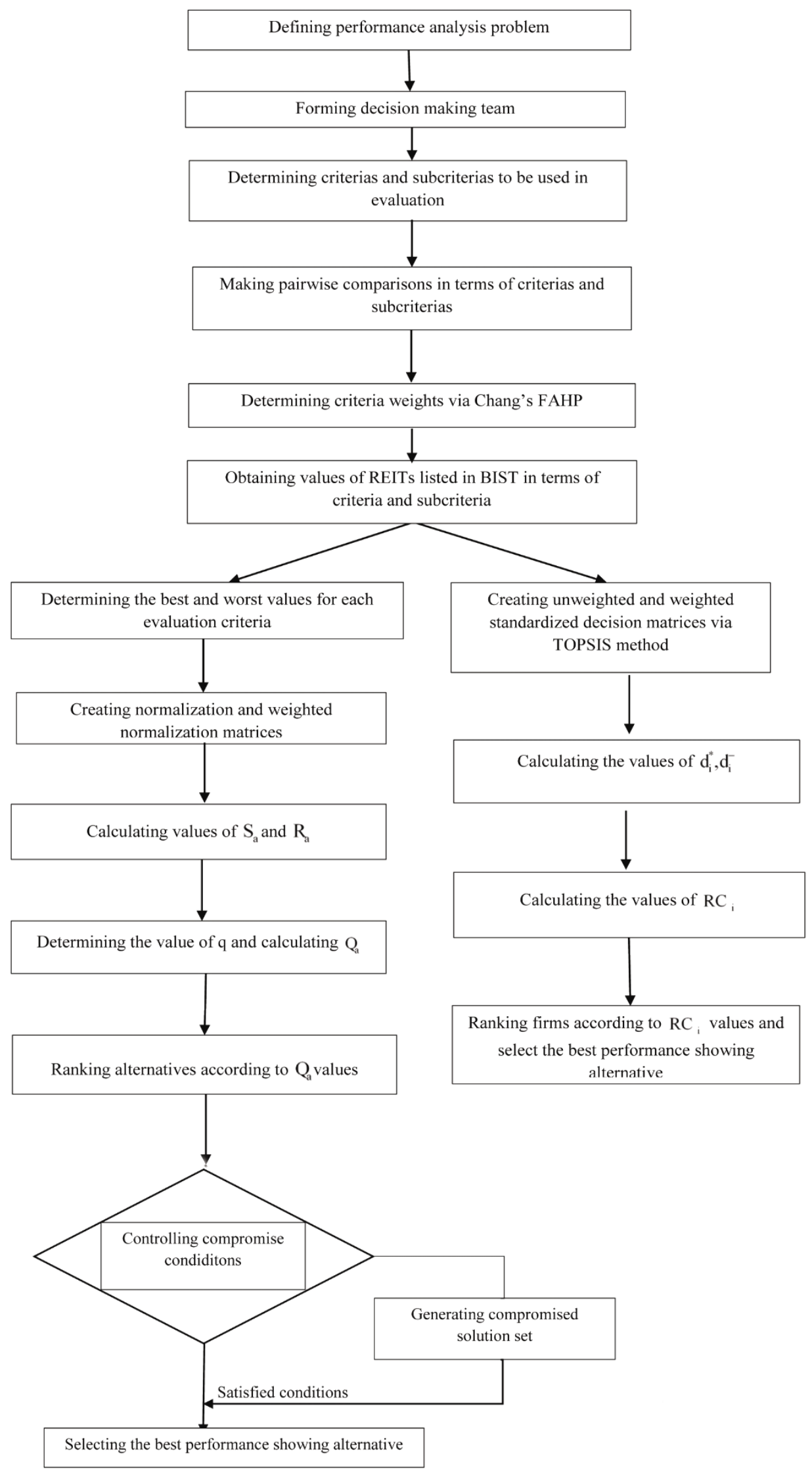

Figure 2. Flowchart of FAHP-VIKOR and FAHP-TOPSIS methodologies 


\section{Results}

In application process a survey evaluating financial ratios was designed and conducted by face-to-face interview. Survey was applied between the dates 8 February 2016 and 20 February 2016 in order to determine weights of criteria for financial indicators. While defining the criteria, first of all, researchers made a depth literature review in order to develop the draft of the scale. 12real estate investment trusts (REIT) listed in BIST are taken into the consideration as alternatives.

Content validity is ensured by consulting to the experts' opinion (especially academicians' from finance field). After these procedures have been completed, data collection process started. Respondents were selected from financial experts worked in universities, public and private sector. Respondents were asked to compare four main criteria with respect to goal on a pair-wise basis to determine their relative importance. Also some demographic information towards respondents was collected and shown in Table 3. As a result, 17 complete surveys were collected and analyzed via Chang's FAHP method.

According to the results of FAHP weights of criteria are given in Table 4. For all comparisons including criteria consistency ratios are under the 0.1 threshold level so comparisons made were consistent. After the weights of criteria are determined, criteria related values of 12 REIT listed in BIST within the period of 2011-2015 are obtained from Public Disclosure Platform and firms' websites.

Table 3. Demographic variables of the study

\begin{tabular}{llcc}
\hline Demographic Variables & & Frequency & Percent $(\%)$ \\
\hline Gender & Female & 10 & 58.82 \\
Age & Male & 7 & 41.18 \\
& $18-30$ & 1 & 5.88 \\
& $31-40$ & 6 & 35.29 \\
Experience in the finance & $41-50$ & 7 & 41.18 \\
& $51-60$ & 3 & 17.64 \\
& $1-3$ & 2 & 11.76 \\
& $4-6$ & 1 & 5.88 \\
Education & $7-9$ & 3 & 17.64 \\
& $10-12$ & 6 & 35.29 \\
Institution & $13+$ & 5 & 29.41 \\
& Bachelor's degree & 2 & 11.76 \\
& Post-graduate & 7 & 41.18 \\
& Doctorate & 8 & 47.05 \\
\hline
\end{tabular}

Table 4. Weights of financial indicators

\begin{tabular}{lc}
\hline Financial Indicators & Weights \\
\hline Return on Assets & 0.255596 \\
Residual Income & 0.249792 \\
Economic Value Added & 0.253283 \\
Return on Sales & 0.241329 \\
\hline
\end{tabular}

According to the importance level of financial indicators, return on assets (ROA) was found as the most important criteria having the value of 0.255596 . On the other hand return on sales was obtained as the least important one having the value of 0.241329 . Relative closeness $\left(R C_{i}\right)$ of each alternative and their rankings within the period of 2011-2014 are obtained via TOPSIS methodology and shown in Table 5. 
Table 5. $R C_{i}$ values and rankings of REITs according to descending order

\begin{tabular}{lcccccccc}
\hline & \multicolumn{2}{c}{$\mathbf{2 0 1 1}$} & \multicolumn{2}{c}{$\mathbf{2 0 1 2}$} & \multicolumn{2}{c}{$\mathbf{2 0 1 3}$} & \multicolumn{2}{c}{$\mathbf{2 0 1 4}$} \\
\cline { 2 - 8 } Firms & $R C_{i}$ & $R a n k$ & $R C_{i}$ & $R a n k$ & $R C_{i}$ & Rank & $R C_{i}$ & Rank \\
\hline NUGYO & 0.363652 & 9 & 0.543981 & 7 & 0.55039 & 5 & 0.241236 & 10 \\
KILLR GYO & 0.527745 & 3 & 0.611882 & 4 & 0.449505 & 9 & 0.358172 & 7 \\
OZGYO & 0.565592 & 2 & 0.379978 & 10 & 0.546754 & 6 & 0.455646 & 3 \\
AGYO & 0.265579 & 10 & 0.867973 & 1 & 0.394781 & 10 & 0.328945 & 8 \\
RYGYO & 0.391972 & 5 & 0.574134 & 5 & 0.666109 & 3 & 0.303036 & 9 \\
SNGYO & 0.162617 & 11 & 0.376843 & 11 & 0.481068 & 8 & 0.585905 & 2 \\
SAY GYO & 0.658891 & 1 & 0.415573 & 9 & 0.48859 & 7 & 0.712948 & 1 \\
TRGYO & 0.474583 & 4 & 0.684152 & 3 & 0.681634 & 1 & 0.405697 & 5 \\
TSGYO & 0.372046 & 6 & 0.565475 & 6 & 0.555685 & 4 & 0.179965 & 11 \\
VKGYO & 0.44857 & 12 & 0.739762 & 2 & 0.681326 & 2 & 0.426156 & 4 \\
YEŞIL GYO & 0.370893 & 7 & 0.278034 & 12 & 0.341443 & 12 & 0.163785 & 12 \\
YKGYO & 0.368939 & 8 & 0.513973 & 8 & 0.377934 & 11 & 0.366939 & 6 \\
\hline
\end{tabular}

According to the firms' ranking related to $R C_{i}$ values YEŞiL GYO shows the worst performance and placed last in the years of 2012, 2013 and 2014; this condition is valid for VKGYO in 2011. However in the context of best financial performance SAY GYO places top position in 2011 and 2014. That is true for AGYO in 2012 and TRGYO in 2013.

By applying VIKOR methodology obtained $S_{a}$ and $R_{a}$ values for each REITs within the period of 2011-2014 are given in Table 6.

Table 6. $S_{a}$ and $R_{a}$ values of REITs

\begin{tabular}{lcccccccc}
\hline & \multicolumn{2}{c}{$\mathbf{2 0 1 1}$} & \multicolumn{2}{c}{$\mathbf{2 0 1 2}$} & \multicolumn{2}{c}{$\mathbf{2 0 1 3}$} & \multicolumn{2}{c}{$\mathbf{2 0 1 4}$} \\
\cline { 2 - 9 } Firms & $S_{a}$ & $R_{a}$ & $S_{a}$ & $R_{a}$ & $S_{a}$ & $R_{a}$ & $S_{a}$ & $R_{a}$ \\
\hline NUGYO & 0.6662 & 0.2298 & 0.5204 & 0.2046 & 0.4471 & 0.1831 & 0.8334 & 0.2555 \\
KILER GYO & 0.4621 & 0.2234 & 0.2738 & 0.1379 & 0.5499 & 0.2052 & 0.6950 & 0.2476 \\
OZGYO & 0.4318 & 0.1846 & 0.5939 & 0.2413 & 0.4231 & 0.1835 & 0.5569 & 0.1823 \\
AGYO & 0.7807 & 0.2413 & 0.1016 & 0.0821 & 0.6024 & 0.1937 & 0.7000 & 0.2263 \\
RYGYO & 0.7019 & 0.2497 & 0.4380 & 0.2442 & 0.2862 & 0.2497 & 0.7322 & 0.2497 \\
SNGYO & 0.8462 & 0.2532 & 0.5898 & 0.1903 & 0.5238 & 0.2413 & 0.3895 & 0.2279 \\
SAY GYO & 0.2276 & 0.2276 & 0.6126 & 0.2430 & 0.4976 & 0.1523 & 0.1829 & 0.1829 \\
TRGYO & 0.5267 & 0.2168 & 0.2218 & 0.1085 & 0.2917 & 0.1017 & 0.6078 & 0.1789 \\
TSGYO & 0.6567 & 0.2327 & 0.3947 & 0.2244 & 0.4055 & 0.1325 & 0.8466 & 0.2451 \\
VKGYO & 0.5749 & 0.2194 & 0.1218 & 0.1033 & 0.2349 & 0.1128 & 0.6009 & 0.2305 \\
YEŞIL GYO & 0.6270 & 0.2240 & 0.8418 & 0.2532 & 0.7695 & 0.2532 & 0.8697 & 0.2532 \\
YKGYO & 0.6950 & 0.2555 & 0.4333 & 0.2555 & 0.5483 & 0.2555 & 0.6781 & 0.2371 \\
\hline
\end{tabular}

In order to obtain $Q_{a}$ values of each alternative, consensus condition is considered and thus parameter (q) showing maximum group benefit is used as 0.5. Ranking of REITs in ascending order after acquiring $Q_{a}$ values are shown in Table 7.

Table 7. $Q_{a}$ values (q=0.5) and rankings of REITs according to ascending order

\begin{tabular}{lcccccccc}
\hline & \multicolumn{2}{c}{$\mathbf{2 0 1 1}$} & \multicolumn{2}{c}{$\mathbf{2 0 1 2}$} & \multicolumn{2}{c}{$\mathbf{2 0 1 3}$} & \multicolumn{2}{c}{$\mathbf{2 0 1 4}$} \\
\hline Firms & $Q_{a}$ & Rank & $Q_{a}$ & Rank & $Q_{a}$ & Rank & $Q_{a}$ & Rank \\
\hline NUGYO & 0.672929 & 7 & 0.635928 & 6 & 0.462957 & 6 & 0.973595 & 11 \\
KİLER GYO & 0.463023 & 3 & 0.277427 & 4 & 0.631075 & 8 & 0.821011 & 8 \\
OZGYO & 0.165058 & 1 & 0.791401 & 10 & 0.44192 & 5 & 0.294426 & 2 \\
AGYO & 0.846415 & 10 & 0 & 1 & 0.642705 & 9 & 0.685582 & 6 \\
RYGYO & 0.842448 & 9 & 0.694473 & 8 & 0.529164 & 7 & 0.862052 & 9 \\
SNGYO & 0.983689 & 12 & 0.641718 & 7 & 0.723814 & 10 & 0.470376 & 4 \\
\hline
\end{tabular}




\begin{tabular}{lcccccccc}
\hline SAY GYO & 0.302993 & 2 & 0.808923 & 11 & 0.410112 & 4 & 0.026468 & 1 \\
TRGYO & 0.468191 & 4 & 0.157561 & 3 & 0.053086 & 2 & 0.309321 & 3 \\
TSGYO & 0.685443 & 8 & 0.60827 & 5 & 0.259539 & 3 & 0.915003 & 10 \\
VKGYO & 0.525846 & 5 & 0.074969 & 2 & 0.035894 & 1 & 0.640665 & 5 \\
YEŞIL GYO & 0.600601 & 6 & 0.993334 & 12 & 0.992482 & 12 & 0.984918 & 12 \\
YKGYO & 0.877756 & 11 & 0.724246 & 9 & 0.793143 & 11 & 0.740488 & 7 \\
\hline
\end{tabular}

According to the $S_{a}, R_{a}$ and $Q_{a}$ values acceptable advantage condition is satisfied for 2011 and 2014. For acceptable advantage condition, difference between first and second alternative having $Q_{a}$ values are greater than or equal the threshold value ( $\mathrm{DQ}=0.090$ for $\mathrm{k}=12$ ). However according to $Q_{a}$ values first alternative get the best score for values of $S_{a}$ and/or $R_{a}$, thus acceptable stability condition is satisfied for four years period (2011-2014).

In terms of firms' ranking related to $Q_{a}$ values YEŞIL GYO shows the worst performance and placed last in the years of 2012, 2013 and 2014 similar as ranking related to $R C_{i}$ values in TOPSIS methodology. Apart from that SNGYO shows the worst performance in 2011.

However in the context of best financial performance, different firms place on the top for each year. In other words OZGYO, AGYO, VKGYO and SAY GYO place top position for each year respectively.

As a result both method give the same output in terms of finding the worst financial performance showing firm as YEŞIL GYO. Additionally they give similar and consistent results in the context of obtaining top five firms showing the best financial performance.

\section{Recommendations and Future Research}

There are not enough studies related to performance analysis of REITs operated in the world and especially for Turkey. In this study performances of REITs listed in BIST are analyzed in the context of different financial indicators and ranked via MCDM methods namely TOPSIS and VIKOR. For this purpose weights of financial indicators are obtained by Chang's extent analysis method on FAHP, one of the mostly used fuzzy ranking method. With these contributions it is aimed to fill the gap in literature. Ultimately both MCDM methods give the same results out of performance of VKGYO in 2011. For further researches it is recommended to integrate the different weights and ranking approaches with different financial indicators with respect to measuring performances of REITs.

\section{References}

Acheampong, J. Y., \& Wetzstein, M. E. (2001). Comperative Analysis of Value-Added and Traditional Measures of Performance: An Efficiency Score Approach. Working Paper, Retreived, May 11, 2016, from http://www.Econbiz.de/Record/comparative-analysis-of-value-added-and-traditional-measures-of-performa nce-an-efficiency -score-approach-acheampong-yvonne/10005493749

Akçay, B. (2000). Türkiye'de Gayrimenkul Yatırım Ortaklıklarının Değerlendirilmesi. Active, 1-9.

Albayrak, E., \& Erensal, Y. C. (2004). Using Analytic Hierarchy Process (AHP) to Improve Human Performance: An Application of Multiple Criteria Decision Making Problem. Journal of Intelligent Manufacturing, 15, 491-503. http://dx.doi.org/10.1023/B:JIMS.0000034112.00652.4c

Alphonce, C. B. (1997). Application of the Analytic Hierarchy Process in Agriculture in Developing Countries. Agricultural Systems, 53(1), 97-112. http://dx.doi.org/ 10.1016/S0308-521X(96)00035-2

Amiri, M. P. (2010). Project Selection For Oil-Fields Development By Using The Ahp And Fuzzy TOPSIS Methods. Expert Systems with Applications, 37(9), 6218-6224. http://dx.doi.org/10.1016/j.eswa.2010.02.103

Awasthi, A., \& Chauhan, S. S. (2012). A Hybrid Approach Integrating Affinity Diagram, AHP And Fuzzy TOPSIS For Sustainable City Logistics Planning. Applied Mathematical Modelling, 36(2), 573-584. http://dx.doi.org/10.1016/j.apm.2011.07.033

Baybordi, A., Barvari, F., Bahramihajlabad, T., \& Sheykhlov, M. (2013). Evaluating the Relationship between Economic Values Added and Stock Return in Companies Listed at Tehran Stock Exchange. Journal of Basic and Applied Scientific Research, 3(2), 1307-1311.

Behzadian, M., Otaghsara, S. K., Yazdani, M., \& Ignatius, J. (2012). A State of Art Survey of TOPSIS $\begin{array}{lllll}\text { Applications. Expert Sytems with Applications, } & 39, & 13051-13069 .\end{array}$ http://dx.doi.org/10.1016/j.eswa.2012.05.056

Bers, M., \& Springer, T. (1997). Economies-of-Scale for Real Estate Investment Trusts. Journal of Real Estate 
Research, 14(3), 275-290. http://dx.doi.org/10.5555/rees.14.3.ft5520n610x00410

Bevilacqua, M., \& Braglia, M. (2000). The Analytic Hierarchy Process Applied to Maintenance Strategy Selection. Reliability Engineering and System Safety, 70, 71-83. http://dx.doi.org/10.1016/S0951-8320(00)00047-8.

Bhushan, N., \& Rai, K. (2004). Strategic Decision Making Applying the Analytic Hierarchy Process. Springer-Verlag London. http://dx.doi.org/10.007/b97668

Biddle, C. G., Bowen, R. M., \& Wallace, J. S. (1997). Does EVA Beat Earning? Evidence on Associations with Stock Returns and Firm Values. Journal of Accounting and Economics, 24, 301-336. http://dx.doi.org/10.1016/S0165-4101(98)00010-X

Bley, J., \& Olson, D. (2005). An Analysis of Relative Return Behavior: REITs vs. Stocks. Academy of Accounting and Financial Studies Journal, 9(2), 71-88. http://dx.doi.org/10.2139/ssrn.391687

Bond, S. A., \& Glascock, J. L. (2006). The Performance and Diversification Benefits of European Public Real Estate Securities. http://dx.doi.org/10.2139/ssrn.896524

Bottani, E., \& Rizzi, A. (2006). A Fuzzy TOPSIS Methodology to Support Outsourcing of Logistics Services. Supply Chain Management: An International Journal, 11(4), 294-308. http://dx.doi.org/10.1108/13598540610671743

Buttimer, R., Hyland, D. C., \& Sanders, A. B. (2001). The Long-run Performance of REIT IPOs. Real Estate Economics, 33, 51-87. http://dx.doi.org/10.1111/j.1080-8620.2005.00112.x

Büyüközkan, G., \& Ruan, D. (2008). Evaluation of Software Development Projects Using a Fuzzy Multi-Criteria Decision Approach. Mathematics and Computers in Simulation, 77, 464-475. http://dx.doi.org/10.1016/j.matcom.2007.11.015

Byun, D. H. (2001). The AHP Approach for Selecting an Automobile Purchase Model. Information and Management, 38(5), 289-297. http://dx.doi.org/10.1016/S0378-7206(00)00071-9

Capital Markets Board. (n. d.). Real Estate Investment Trusts. Retreived February 16, 2016 from http://www.spk.gov.tr/indexcont.aspx?action=showpage \&menuid=16\&pid=2

Chang, D. Y. (1996). Applications of the extent analysis method on fuzzy AHP. European Journal of Operational Research, 95, 649-655. http://dx.doi.org/10.1016/0377-2217(95)00300-2

Chang, G. D., \& Chang, Y. T. (2010). Time-Varying Risk Premia for Size Effcets on Equity REITs. Retreived February 14, 2016 from http://www.apjfs.org/conference/2010/cafm2010/11-2.pdf

Chen, C. T., Lin, C. T., \& Huang, S. F. (2006). A fuzzy approach for supplier evaluation and selection in supply chain management. International Journal of Production Economics, 102, 289-301. http://dx.doi.org/10.1016/j.ijpe.2005.03.009

Chen, L. Y., \& Wang, T. (2009). Optimizing Partners' Choice in IS/IT Outsourcing Process: The Strategic Decision for Fuzzy VIKOR. International Journal of Production Economics, 120(1), 233-242. http://dx.doi.org/10.1016/j.ijpe.2008.07.022

Chen, S., \& Dodd, J. L. (1998). Usefulness of Operating Income, Residual Income and EVA: A Value-Relevance Perspective. MBAA Conference, İllinois, March 28, Chicago.

Chen, S. J., Hsieh, C., Vines, T. W., \& Chiou, S. N. (1998). Macroeconomic Variables, Firm-Specific Variable and Returns to REITs. The Journal of Real Estate Research, 16(3), 269-277.

Ching, L. Z., \& Been, Y. C. (1996). Evaluation of Machine Selection by the AHP Method. Journal of Materials Processing Technology, 57(3), 253-258. http://dx.doi.org/10.1016/0924-0136(95)02076-4

Chu, T. C. (2002). Facility Location Selection Using Fuzzy TOPSIS Under Group Decisions. International Journal of Uncertainty, Fuzziness and Knowledge-Based Systems, 10, 687-701. http://dx.doi.org/10.1142/S0218488502001739

Chuang, P. T. (2001). Combining The Analytic Hierarchy Process And Quality Function Deployment for a Location Decision From a Requirement Perspective. The International Journal of Advanced Manufacturing Technology, 18(11), 842-849. http://dx.doi.org/10.1007/s001700170010

Derwall, J., Huij, J., Brounen, D., \& Marquering, W. (2009). REIT Momentum and The Performance of Real Estate Mutual Funds. Financial Analysts Journal, 65(5), 24-34. http://dx.doi.org/10.2469/faj.v65.n5.4

Ertuğrul, İ., \& Karakaşoğlu, N. (2009). Banka Şube Performanslarının VIKOR Yöntemi İle Değerlendirilmesi. 
Endüstri Mühendisliği Dergisi, 20(1), 19-28.

Frei, F. X., \& Harker, P. T. (1999). Measuring Aggregate Process Performance Using AHP. European Journal of Operational Research, 116(2), 436-442. http://dx.doi.org/10.1016/S0377-2217(98)00134-9

Glascock, J. L., Lu, C., \& So, R. W. (2006). Excess Return and Risk Characteristics of Asian Exchange Listed Real Estate. http://dx.doi.org/10.2139/ssrn.907427

Goebel, P. R., Harrison, D. M., Mercer, J. M., \& Whitby, R. J. (2013). REIT Momentum and Characteristic-Related REIT Returns. Journal of Real Estate Finance and Economics, 47(3), 564-581. http://dx.doi.org/10.1007/s11146-012-9371-2

Goebel, P. R., \& Kim, K. S. (1989). Performance Evaluation of Finite-Life Real Estate Investment Trusts. The Journal of Real Estate Research, 4(2), 57-69. http://dx.doi.org/10.5555/rees.4.2.8272p1q8114m5631

Güngör, Z., \& Arikan, F. (2007). Using fuzzy decision making system to improve quality-based investment. Journal of Intelligent Manufacturing, 18(2), 197-207. http://dx.doi.org/10.1007/s10845-007-0016-X

Güven, M. (2006). Gayrimenkul Yatırım Ortaklıklarl ve Gayrimenkul Yatırım Ortaklıklarl Hisse Senetlerinin Verimini Etkileyen Faktörler Üzerine IMKB’de Bir Uygulama. Yayınlanmamış Yüksek Lisans Tezi, İstanbul Üniversitesi.

Han, J., \& Liang, Y. (1995). The Historical Performance of Real Estate Investment Trusts. The Journal of Real Estate Research, 10(3), 235-262. http://dx.doi.org/10.5555/rees.10.3.w0675qr383987686

Hwang, C. L., \& Yoon, K. (1981). Multiple Attribute Decision Making: Methods and Application. Springer, NewYork. http://dx.doi.org/10.1007/978-3-642-48318-9

Hwang, H. S., Moon, C., Chuang, C. L., \& Goan, M. J. (2005). Supplier Selection Planning Model Using AHP. International Journal of The Systems for Logistics and Management, 1(1), 47-53.

Kiler GYO (n. d.). Financial Reports. Retreived February 9, 2016 from http://www.kilergyo.com/yatirimci_platformu.html

Kuhle, J. L., \& Walther, C. H. (1987). REITs vs. Common Stock Investments: An Historical Perspective: A Survey of Performance Results, 1973-1984. Real Estate Finance, 3(1), 452-477.

Lehn, K., \& Makhija, A. (1997). EVA, Accounting Profits and CEO Turnover: An Empirical Examination:1985-1994. Journal of Applied Corporate Finance, 10(2), 90-97. http://dx.doi.org/10.1111/j.1745-6622.1997.tb00139.x

Liou, J. J. H., \& Chuang, Y. T. (2010). Developing a Hybrid Multi Criteria Model for Selection of Outsourcing Providers. Expert Systems with Applications, $3755-3761$. http://dx.doi.org/10.1016/j.eswa.2009.11.048

Lixin, D., Ying, L., \& Zhiguang, Z. (2008). Selection of Logistics Service Provider Based on Analytic Network Process and VIKOR Algorithm. Networking, Sensing and Control, ICNSC 2008-IEEE International Conference Proceedings, 1207-1210. http://dx.doi.org/10.1109/ICNSC.2008.4525400

Marts, B. A., \& Elayan, F. A. (1990). Capital Structure and the Cost of Capital for Untaxed Firms: The Case of REITs. Real Estate Economics, 18(1), 22-39. http://dx.doi.org/10.1111/1540-6229.00507

McIntosh, W., Liang, Y., \& Tompkins, D. L. (1991). An examination of the small-firm effect within the REIT industry. Journal of Real Estate Research, 6(1), 9-17.

Niskanen, J., Rouhento, J., \& Falkenbach, H. (2011). European real estate equities: Ownership structure and value of the firm. Journal of European real estate research, 3(2), 131-143. http://dx.doi.org/10.1108/17539261111157307

Nurol GYO. (n.d.). Financial Reports. Retreived February 8, 2016 from http://www.nurolgyo.com.tr/tr/yatirimci-iliskileri/detay/Finansal-Raporlar/28/0/0

Opricovic, S., \& Tzeng, G. H. (2004). The Compromise Solution by MCDM Methods: A Comparative Analysis of VIKOR and TOPSIS. European Journal of Operational Research, 178(1), 445-455. http://dx.doi.org/10.1016/S0377-2217(03)00020-1

Opricovic, S., \& Tzeng, G. H. (2007). Extended VIKOR Method in Comparison with Other Outranking Methods. European Journal of Operational Research, 178(2), 514-529. http://dx.doi.org/10.1016/j.ejor.2006.01.020

Ozak GYO (n. d.). Financial Reports. Retreived February 18, 2016 from 
http://www.ozakgyo.com/sayfa.aspx?id=12\&dilid=1\&type=1

Özdemir, B., \& Türker, F. (2007). 2002-2006 Döneminde Türkiye'de Gayrimenkul Yatırım Ortaklıklarına Enflasyon ve Faiz Oranlarinin Etkisi. Retreived January 14, 2016 from http://paribus.tr.googlepages.com/ozdemir_turker.pdf

Özderici GYO (n. d.). Financial Reports. Retreived February 15, 2016 from http://www.ozdericigyo.com.tr/content.php?id=55

Öztürk, H. (2010). Artık Kâr, Özsermayeye Serbest Nakit Akımı ve Defter Değerlerinin Şirketlerin Piyasa Değerleri Üzerindeki Etkileri: IMKB'de Ampirik Bir Uygulama. Maliye Finans Yazıları, 24(89), 49-72.

Peterson, J. D., \& Hsieh, C. H. (1997). Do Common Risk Factors in the Returns on Stocks and Bonds Explain Returns on REITs? Real Estate Economics, 25(2), 321-345. http://dx.doi.org/10.1111/1540-6229.00717

Public Disclosure Platform (n. d.). Financial Tables. Retreived February 10, 2016, from https://www.kap.gov.tr/

Reysas GYO (n. d.). Financial Reports. Retreived February 14, 2016, from http://www.reysasgyo.com.tr/mali-raporlar

Richman, M. B., Forman, E. H., Bayazit, Y., Einstein, D. B., Resnick, M. I., \& Stovsky, M. D. (2006). A Novel Computer Based Expert Decision Making Model for Prostate Cancer Disease Management. The Journal of Urology, 174, 2310-2318. http://dx.doi.org/10.1097/01.ju.0000181829.07078.22

Saaty, T. L. (1980). The Analytic Hierarchy Process. McGraw- Hill International, New York, NY.

Saaty, T. L. (1990). How To Make A Decision: The Analytic Hierarchy Process. European Journal of Operation Research, 48, 9-26. http://dx.doi.org/10.1016/0377-2217(90)90057-I

Saaty, T. L. (2008). Decision Making with the Analytic Hierarchy Process. International Journal of Services Sciences, 1(1), 83-98. http://dx.doi.org/10.1504/IJSSci.2008.01759

Saaty, T. L., \& Vargas, L.G. (2012). Models, Methods, Concepts \& Applications of the Analytic Hierarchy Process (AHP). Springer US: Boston. http://dx.doi.org/10.1007/978-I-4614-3597-6

Şahin, C. (2014). Firmaya Özgü Değişkenlerle Gayrimenkul Yatırım Ortaklıkları (GYO) Getirisi Arasındaki İlişkiyi İncelemeye Yönelik Bir Uygulama. Dumlupınar Üniversitesi Sosyal Bilimler Dergisi, 42, 11-18.

Shahanaghi, K., \& Yazdian, S. A. (2009). Vendor Selection Using a New Fuzzy Group TOPSIS Approach. Journal of Uncertain Systems, 3(3), 221-231.

Shanian, A., \& Savadogo, O. (2010). A Methodological Concept for Material Selection of Highly Sensitive Components Based on Multiple Criteria Decision Analysis. Expert Systems with Applications, 36, 1362-1370. http://dx.doi.org/10.1016/j.eswa.2007.11.052

Sinpas GYO. (n. d.). Financial Reports. Retreived February 16, 2016 from https://www.sinpasgyo.com/tr-TR/FinancialStatements.aspx

Smith, K. V., \& Shulman, D. (1976). The Performance of Equity Real Estate Investment Trusts. Financial Analysts Journal, 32(5), 61-66. http://dx.doi.org/10.2469/faj.v32.n5.61

Titman, S., \& Warga, A. (1986). Risk and the Performance of the Real Estate Investment Trusts: A Multiple Index Approach. AREUEA Journal, 14(3), 414-431. http://dx.doi.org/10.1111/1540-6229.00395

Torunlar GYO. (n.d.). Financial Reports. Retreived February 15, 2016 from http://www.torunlargyo.com.tr/yatirimci_iliskileri.php

Tsaur, R. C. (2011). Decision Risk Analysis For an Interval TOPSIS Method. Applied Mathematics and Computation, 218, 4295-4304. http://dx.doi.org/10.1016/j.amc.2011.10.001

TSGYO. (n.d.). Financial Reports. Retreived February 19, 2016 from http://www.tskbgyo.com.tr/yatirimci-iliskileri

Tzeng, G. H., Lin, C. W., \& Opricovic, S. (2005). Multi-criteria Analysis of Alternative-Fuel Buses for Public Transportation. Energy Policy, 33, 1373-1383. http://dx.doi.org/10.1016/j.enpol.2003.12.014

US Securities and Exchange Commussion. (n. d.). Real Estate Investment Trusts. Retrieved May 11, 2016 from https://www.sec.gov/answers/reits.htm

Vakıf GYO. (n.d.). Financial Reports. Retreived February 20, 2016 from http://www.vakifgyo.com.tr/sayfalar.asp?LanguageID=1\&cid=5\&id=32\&id2=54 
Wang, Y. M., Luo, Y., \& Hua, Z. (2008). On the extend analysis method for fuzzy AHP and it's applications. European Journal of Operational Research, 186(2), 735-747. http://dx.doi.org/10.1016/j.ejor.2007.01.050

Worthington, C. A., \& West, T. (2004). Australian Evidence Concerning the Informatioan Centent of Economic $\begin{array}{llll}\text { Value-Added. Australian Journal of } & \text { Management, 29(2), }\end{array}$ http://dx.doi.org/10.1177/031289620402900204

Wu, H. Y., Tzengh, G. H., \& Chen, Y. H. (2009). A Fuzzy MCDM Approach for Evaluating Banking Performance Based on Balanced Scorecard. Expert Systems with Applications, 36, 10135-10147. http://dx.doi.org/10.1016/j.eswa.2009.01.005

Wua, H. Y., Tzeng, G. H., \& Chen, Y. H. (2009). A Fuzzy MCDM Approach For Evaluating Banking Performance Based on Balanced Scorecard. Expert Systems with Applications, 36(6), 10135-10147. http://dx.doi.org/10.1016/j.eswa.2009.01.005

Yavuzarslan, E. (2007). Artık Kâr Yönetimi ve Şirket Değerlemesinde Kullanımı. Yayınlanmamış Yüksek Lisans Tezi, Ankara Üniversitesi.

Yesil GYO. (n.d.). Financial Reports. Retreived February 13, 2016 from http://www.yesilgyo.com/faaliyet-raporlari.php

Yetkin, F. (2004). Gayrimenkul Yatırım Ortaklıklarının Performans Değerlemesi. Active, 1-13.

YKGYO. (n. d.). Financial Reports. Retreived February 15, 2016 from http://www.yapikredikoray.com/MaliTablolarveDipnotlar.aspx

Yong, J., Allen, D. E., \& Lim, L. K. (2009). AREIT returns from 1990-2008: A multi-factor approach. Paper presented at the 18th World IMACS/MODSIM Congress, Cairns, Australia. Retreived February 12, 2016 from http://mssanz.org.au/modsim09

Yurdakul, M., \& İç, Y. T. (2003). Türk Otomotiv Firmalarının Performans Ölçümü ve Analizine Yönelik TOPSIS Yöntemini Kullanan Bir Ölçek Çalışma. Gazi Üniversitesi Mühendislik Mimarlık Fakültesi Dergisi, 18(1), $1-18$.

Yurdakul, M., \& İç, Y. T. (2009). Analysis of The Benefit Generated By Using Fuzzy Numbers in a TOPSIS Model Developed for Machine Tool Selection Problems. Journal of Materials Processing Technology, 209, 310-317. http://dx.doi.org/10.1016/j.jmatprotec.2008.02.006

Yücenur, G. N., \& Demirel, N. Ç. (2012). Group Decision Making Process for Insurance Company Selection Problem with Extended VIKOR Method Under Fuzzy Environment. Expert Systems with Applications, 39, 3702-3707. http://dx.doi.org/10.1016/j.eswa.2011.09.065

Yükçü, S., \& Atağan, G. (2009). TOPSIS Yöntemine Göre Performans Değerleme. Journal of Accounting \& Finance, 45, 28-35.

Yüksek, İ., \& Akın, A. (2006). Analitik Hiyerarşi Proses Yöntemiyle İşletmelerde Strateji Belirleme. Doğuş Üniversitesi Dergisi, 7(2), 254-268. Retreived January 12, 2016 from http://journal.dogus.edu.tr/index.php/duj/article/view/113

Zhou, Y., Maumbe, K., Deng, J., \& Selin, S. W. (2015). Resource-based Destination Competitiveness Evaluation Using a Hybrid Analytic Hierarchy Process (AHP): The Case Study of West Virginia. Tourism Management Perspectives, 15, 72-80. http://dx.doi.org/10.1016/j.tmp.2015.03.007

\section{Copyrights}

Copyright for this article is retained by the author(s), with first publication rights granted to the journal.

This is an open-access article distributed under the terms and conditions of the Creative Commons Attribution license (http://creativecommons.org/licenses/by/3.0/). 